Premise : Journal of English Education and Applied Linguistics

https://fkip.ummetro.ac.id/journal/index.php/english

Sari and Iswahyuni

\title{
THE STUDENTS' SPEAKING ANXIETY \\ ON THE YOUTUBE VIDEO PROJECT IN EFL LEARNING IN \\ INDONESIA
}

by

\author{
Angela Bayu Pertama Sari \\ ORCID: https://orcid.org/0000-0003-2859-2645 \\ Universitas Bina Sarana Informatika, Jakarta Indonesia \\ angela.abp@bsi.ac.id \\ Dwi Iswahyuni \\ Universitas Bina Sarana Informatika, Jakarta Indonesia \\ dwi.dhs@bsi.ac.id
}

Received: August 13, 2019

Resent Back: August 28, 2019

Accepted: September 30, 2019
Reviewed: August 26, 2019

Revised: September 27, 2019

Published: October 19, 2019

\begin{abstract}
:
This research aimed to portray the occurrence of anxiety in the YouTube video project conducted by non-English students. It was descriptive-qualitative research. One hundred twenty-four students participated in this research. The research findings showed that 65 students felt the anxiety, and 59 were not anxious in doing the YouTube video project. There was a slight difference between those two findings. Some factors influenced the students' anxiety, namely students' low personal perception, peers' negative judgment, and quite intimidating learning environment. While the factors that support the absence of anxiety were students' positive own perception and fun-less intimidating and encouraging learning environment. However, the research finding highlighted that YouTube video project was the preferable media that was based on the 104 students' responses claiming that they prefer doing YouTube video project than other speaking activities such as storytelling, oral presentation, and speech.
\end{abstract}

Keywords: YouTube, video project, speaking anxiety

\section{INTRODUCTION}

The ever-growing necessity of proficient English communication creates all humans, particularly the non-native speaker, to endeavour in achieving the demanded English proficiency. It is in line with (Mahmoodzadeh, 2012) who claims that all people around the 
globe should improve their English skills to cope with the need for this current and future communication environment. It is all due to the position of English as becoming one of the universal languages in the world. Besides, (Ahmed, Pathan, \& Khan, 2017) state that the rising demand for language proficiency in the international setting has put English in a considerable status among all languages.

In English communication, the mastery of speaking skills plays a more significant role than any other language skills. Zaremba (2006), as cited in (Boonkit, 2010), proposes that among the four macro skills of English, speaking skills is the most necessary skills needed in the communication process. Moreover, (Hanifa, 2018) explains that a considerable number of language learners, particularly English language learners, set their objectives in improving their communication skills through speaking. It is believed that productive oral communication is the key to handle English communication in the real setting.

However, the fact shows that in the English classroom, students have limited English oral exposure and also few opportunities outside the school to practice their speaking (Zhang, 2009). Some problems are raised in the practice of English speaking. Several types of research have found that one of the difficulties in speaking that is relatively high is the anxiety to speak in English.

Anxiety is defined as a negative way to express what someone feels. When someone is anxious, he or she feels nervous, worried, and fearful (Ansari, 2015). It is also believed that anxiety may cause tremble, quick heartbeat, startled, and other unpredictable, strange behaviors. Anxiety in language learning is an alarming problem since it obstructs learners to engage in speaking communication. Moreover, Young 1991, as cited in (Ahmed et al., 2017)states that anxiety brings impact not only to the willingness to speak but also to the quality of the speaking production. Speaking anxiety in language learning is the primary barrier in language learning so that learners should overcome it (Harmer, 2004).

There is plenty of factors influencing the anxiety perceived by the students. The first one is the fear of speaking in the public or the front of many people. Students in the language classroom are anxious when they are asked to speak in front of their peers (Ahmed et al., 2017). The anxiety is due to the verbal action that they perform (Bozavli \& Gulmez, 2012). Verbal production requires lots of aspects such as pronunciation, intonation, accent, stress, and other Premise Journal Vol. 8 No 2, October 2019, e-ISSN: 2442-482x, p-ISSN: 2089-3345, p.176-192 Copyright@2019 by PJEE 
spoken language elements. Besides, language elements such as grammar and vocabulary are also needed in spoken communication.

Some students are not confident in their English proficiency. The unconfident feeling leads to the fear of making mistakes in speaking that is considered as the second factor influencing students' anxiety. The anxiety of committing grammatical error is one of the primary reason that hinders the students from speaking up (Mahmoodzadeh, 2012). Not only grammatical errors but also the inappropriate choice of vocabularies and colocations plays a role in the students' speaking reluctance (Kasbi \& Elahi Shirvan, 2017). Furthermore, students must know what they want to say so that clear pronunciation and correct word order can be achieved to support their self-confidence (Hanifa, 2018). For those who are lack of that language mastery, they are typically feeling unsure of what they intend to say and end up to becoming anxious.

The act of making grammatical mistakes are so scary for the students since it causes humiliation by their classmates. Spontaneous mocking happens a lot in the language classroom when the students make mistakes; they are somehow automatically got mocked, judged, and criticized by their classmates. For some students, they find it as a common experience as a part of learning; however, for the majority of students, the worry feeling by being viewed negatively in the eyes of others lead to anxiety in speaking (Çağatay, 2015). Being the subject of a laugh in class and also being judged as having the low ability are also other reasons underlying the students' speaking anxiety (Ansari, 2015).

Another factor influencing the anxiety is the unfamiliarity in using the language. A minimal chance to speak in English creates few opportunities to practice their skills in communication. The rare opportunity of English speaking creates unfamiliarity then causes difficulty to speak up. Moreover, the students are not accustomed to expand their knowledge to establish communication in English. Also, the students find many unfamiliar topics to be discussed in the conversation that make them unwilling to communicate (Kasbi \& Elahi Shirvan, 2017).

In regards to the students' anxiety, some prior studies have been conducted. One of which is the use of a video project. A study from (Hafner \& Miller, 2011) and (Vanderplank, 2010) discovers that video project is believed to be an effective media to lessen the anxiety 
since it appears providing a highly motivated impact to the students that they can find exciting, challenging and meaningful learning in it. Other study that is conducted by (Duffy, 2008) shows that the video project learning also shifts the traditional education into today's electronic learning culture that is more suitable to the learning characteristics of today's students. Moreover, a study by (Nikitina, 2010) reveals that not only increasing the students' motivation, but video project learning also eases the learning process because it gives learners' chance to practice the language in a more meaningful context with their strategies. The impact of peer work in video project learning also contributes positively to the learning process. It provides cooperative learning so that the students can learn from their peers and makes all students integrated into learning activities (Aksel \& Gürman-kahraman, 2014). Furthermore, the finding from the research that was conducted by (Ellis, 2012) video project learning provides a less threatening learning environment compared to the individual learning activities that put them in a more under pressured situation.

A study that was done by (Roodt \& Peier, 2013) suggests that there are 20 potential learning outcomes from the implementation of video project learning. YouTube is an online platform that enables users to share and access content in the form of videos (Duffy, 2008). The beneficial value of YouTube is also claimed a study conducted by (Tan \& Pearce, 2011) by emphasizing that YouTube is an effective media for language learning. A research by (Roodt \& Peier, 2013) emphasizes that the effectiveness of YouTube media for language learning is due to the ability to providing flexible education and in-depth exploration of the language learning for the students in the level of undergraduate and postgraduate

Moreover, the learning activities by creating a video is believed to be a valuable learning exercise (Duffy, 2008). Furthermore, the value of that video content becomes more meaningful when it is uploaded and can be accessed by the public. Many researchers believe that YouTube is an innovative platform that engages today's students in language (Roodt \& Peier, 2013). Furthermore, there are 2 other studies that investigate the speaking anxiety. The first one is (Nurlaili \& Kurniasih, 2016) reveals that the causes of speaking anxiety are classroom procedure and language testing. Thus, modification and innovation are needed to be done. Then, (Tercan \& Dikilitas, 2015) stated that speaking skills teaching should be done in socially non- 
threatening setting. Accordingly, YouTube video project can be one of the alternative to achieve that kind of learning environment.

The gap of this research with the prior studies is in terms of YouTube usage for the contribution to the students' anxiety. The prior studies have already found out that video project is a quite significant media for managing the students' anxiety in class. However, there is minimum discussion on the use of YouTube platform for the goal of minimizing the students' anxiety in speaking.

By considering the issues in speaking anxiety and the potential learning platform that is video project in YouTube, the researcher aims at answering the two research questions: (1) Does speaking anxiety exists in the YouTube Video Project conducted by EFL learners? (2) How do some factors influence the presence and the absence of speaking anxiety in the YouTube Video Project conducted by EFL learners?

There is one objective that the researchers aim to achieve that is to provide a thorough explanation about the presence and the absence of speaking anxiety in the YouTube video projects that are conducted by the EFL learners in Indonesia. The study endeavours to examine whether the students' anxiety exists in the process of making the video project or not. Moreover, the factors that cause that occurrences will also be dig out further through the students' responses.

The focus of this study is to expose the use of YouTube platform as an effort to minimize the students' anxiety to speak English. YouTube is widely used by the students today and it has a potential value for the English learning. Thus, by selecting YouTube as the platform for the video project result publication, the researchers predict that the possibility to achieve the objective is greater.

At last, by conducting this study, the researchers have a mission to contribute to the enrichment of the knowledge about the online learning media for the video project. There is still limited exploration on the video project assignment by using YouTube, thus this research reveals to what aspects of video project in YouTube platform that are effective to minimize the students anxiety and also other aspects that are not. Hence, the future English teachers or lecturers may benefit from the findings of the exploration of video project in YouTube platform for minimizing students' anxiety.

Premise Journal Vol. 8 No 2, October 2019, e-ISSN: 2442-482x, p-ISSN: 2089-3345, p.176-192 Copyright@2019 by PJEE 


\section{METHOD}

\section{Design}

This study was qualitative research to dig out thorough information (Kawulich, 2015). Moreover, it pointed out to describe the phenomenon or characteristics. In this case, the research objective was to describe the presence and the absence of speaking anxiety through observation and data collected from the students.

\section{Participant}

The subject of this research were 124 non-English students who were taking General English or English Foreign Language class. Those students were majoring in Pharmacy and Mathematics Education at Sanata Dharma University Yogyakarta, Indonesia. Those students were in the 6th and 3rd semester.

\section{Instrument and Data Sources}

The source was qualitative data in the form of phrases and sentences from the openended question asked to the 124 non-English students joining the General English class as the English Foreign Language class. The students answered it in a written form so that it can be recorded as the research data.

\section{Data Collecting Technique}

In this qualitative descriptive research, the data were taken from the open-ended questions that were asked to the students, then it was written in papers. There were two questions asked: (1) Do they feel anxious/ afraid/ fearful when they create the YouTube video project (with reasons)? (2) What is their most preferable media for the speaking activities that may lessen down their anxiety? The data were also enriched with the data taken from the observation of the video project result that can be accessed on YouTube. The researcher then took note on the students' performances seen in the videos. 


\section{Data Analysis Technique}

The analysis in this research was based on the descriptive qualitative analysis by (Miles, Huberman, \& Saldana, 2014). Three stages were conducted in this analysis; the first cycle was coding that initially examined the data by using in vivo coding, focusing on the students' words, short phrases, and languages. Then, it continued to the second cycle that was pattern coding that grouped the data into categories. The last one was the narrative description that elaborated and narrated the result from the previous categories.

\section{RESULT AND DISCUSSION}

\section{Result}

The data were collected in the form of students' phrases and sentences that yielded three significant categories. There was category dealing with students who were anxious along with the influencing factors; the category showing the students who were not anxious along with the reasons; and the category preferable learning media of speaking activities. According to the 124 students' responses, the results of the research were presented in table 1, 2, and 3. Each student answered the questions given by the researcher. The data showed that from 1 student's responses, it yielded one or more responses that belonged to different categories.

\section{The presence of anxiety in YouTube video project}

Table 1

The presence of anxiety in YouTube video project

\begin{tabular}{|l|l|c|}
\hline Code & \multicolumn{1}{|c|}{ Students' Responses } & $\begin{array}{c}\text { Frequency } \\
\text { (65 students) }\end{array}$ \\
\hline A1 & Nervous & 7 \\
\hline A2 & Afraid / Embarrassed of mistakes (grammar, pronunciation, intonation) & 34 \\
\hline A3 & Embarrassed by being recorded by using the camera & 5 \\
\hline A4 & Worried of friends' judgment, harsh comments, humiliation & 9 \\
\hline A5 & Unconfident of English speaking skills & 10 \\
\hline A6 & Ashamed of performing thick Javanese accent & 2 \\
\hline A7 & Worried about the publication of the video project in YouTube & 6 \\
\hline A8 & Not accustomed to speaking in English & 11 \\
\hline A9 & Worried that what they said cannot be understood by the audiences & 8 \\
\hline
\end{tabular}

Premise Journal Vol. 8 No 2, October 2019, e-ISSN: 2442-482x, p-ISSN: 2089-3345, p.176-192

Copyright@2019byPJEE 
Sixty-five students felt anxious about the process of a YouTube video project. The number showed that more than half of the students were anxious about doing the YouTube video project. The most significant factors that made them anxious came from their selfperception: 34 students were afraid and embarrassed by making mistakes; 7 students felt nervous; 10 students felt unconfident with their English skills, and two students felt ashamed of their thick dialect accent of Javanese.

Then the other factors influencing the students' anxiety dealt with what other people's judgment about their English performances. There were nine students who felt insecure about their friends' opinion, harsh comments, and humiliation, and eight students were worried that the audiences could not understand the utterance that they said in their video project.

The last factor that affected the students' anxiety was related to the English learning environment. The result showed that five students were embarrassed by being recorded in a video and six students were not comfortable with the fact showing that the result of the video will be published in YouTube platform and could be accessed by the public. Eleven students stated that they were not accustomed to speaking in English. They had limited chance to speak English outside the classroom.

\section{The absence of anxiety in YouTube video project}

Table 2

The absence of anxiety in YouTube video project

\begin{tabular}{|l|l|c|}
\hline Code & \multicolumn{1}{|c|}{ Students' Responses } & $\begin{array}{c}\text { Frequency } \\
\text { (59 students) }\end{array}$ \\
\hline N1 & $\begin{array}{l}\text { Perceive that vocabularies used were simple and not difficult, feel positive } \\
\text { about the vocabularies and plan to learn more }\end{array}$ & 3 \\
\hline N2 & The language performance can be revised, edited and retaken & 8 \\
\hline N3 & $\begin{array}{l}\text { Feel confident since video project making was only seen by the friends in } \\
\text { their group }\end{array}$ & 15 \\
\hline N4 & It provides more preparation & 7 \\
\hline N5 & $\begin{array}{l}\text { They believed that video project was a media to improve their English } \\
\text { skills }\end{array}$ & 27 \\
\hline N6 & They were aware that making mistakes was a part of the learning process & 11 \\
\hline N7 & More freedom in performing language & 2 \\
\hline N8 & A fun way to learn English & 3 \\
\hline N9 & They were accustomed to speak in English \\
\hline
\end{tabular}


The result showed that 59 students did not feel anxious about doing the YouTube video project. This number was slightly fewer than the number of students who felt anxious about the different gap of 6 students. The major factors influencing this occurrence were from their positive perceptions to their English performances and the process of YouTube video making. Twenty-seven students believed that this video project could help them improve their English skills. Eleven students were aware that making mistakes was reasonable, and it was a part of the learning process. Three students felt positive with the vocabularies that they produced and planned to learn it more profound.

The other factors that support the students so that they did not feel anxious were the English learning environments of the video project making. Fifteen students felt confident with the fact that during the video-making process, the only people who saw their English performances were their group mates. Eight students considered the video project as a fun way to learn a language. Seven students perceived that the video project provided them more time to prepare for achieving the best result. Moreover, eight students observed that YouTube features enable them to revise, edit, and retake the video for gaining the best result that they expected. Three students felt that speaking English was not hard since they were already accustomed to speaking in English outside the classroom. 2 students thought that they got more freedom in expressing ideas with the English language.

\section{Students' preferable media other than video project in speaking activities}

Table 4

Students' preferred media other than video project in speaking activities

\begin{tabular}{|c|c|}
\hline Students' preferred activity for speaking & Frequency \\
\hline YouTube video project & 104 \\
\hline Storytelling, Presentation, Speech & 20 \\
\hline
\end{tabular}

The result in table 3 showed that the majority of the students that was 104 students preferred video project than other media. Then 20 of them prefer activities other than YouTube video project, namely storytelling, oral presentation, and delivering a speech. 
The results showed that speaking anxiety appeared in the YouTube video project. Sixty-five students felt the anxiety; while 59 students were anxious-free. Several factors hold the role in this occurrence that was elaborated as follows.

\section{Students' anxiety in the YouTube video project}

Sixty-five students from a total of 124 students, perceived the speaking anxiety. Three factors were influencing this occurrence. The first one was a personal perception from within the students' themselves. Seven students were nervous as a reflection of their anxiety. This kind of feeling was sometimes uncontrollable so that the students must struggle to manage it. Ten students were also unconfident to their English proficiency. They were worried about the skills that they had due to low self-esteem. Anxiety had a close relation to this occurrence. It was in line with (Ansari, 2015) stating that someone anxious felt nervous, worried, and fearful. Not only the factor of tense, but the factor of fear making mistakes also became the major factors in speaking. A large number of students, 34 students, were afraid of making grammatical, pronunciation, and intonation mistakes. It was one of the reasons why they were anxious about doing the YouTube video project.

Moreover, few students were ashamed of their speaking accent. The native language of Javanese made them have a thick accent of Javanese language. It caused their English pronunciation and intonation sound not similar to the native speakers' utterance that commonly considered by their peers as making mistakes. The students then felt ashamed due to it that subsequently led to anxiety. Those occurrences were supported by (Mahmoodzadeh, 2012), confirming that the worry of making grammatical errors was one of the primary reasons that caused anxiety. Furthermore,(Kasbi \& Elahi Shirvan, 2017) also stated a similar point that was errors in pronunciation and collocation hold a role in creating the students' anxiety in speaking.

The second factors that gave impact to the students' anxiety were the peers' negative attitudes to their English performances. Nine students were afraid of being judged and humiliated due to their imperfection of English. Some experts supported this fact that happened in the classroom. The fear of being viewed negatively in the eyes of others raised anxiety (Çağatay, 2015). Furthermore, the embarrassed feeling as being the subject of a laugh in class and also the uncomfortable feeling as being judged having the low ability in English gave 
massive impact to the students' reluctance in speaking (Ansari, 2015). Next, (Hanifa, 2018), suggested that the students must know what they say to support their self-confidence by producing clear pronunciation and correct word order.

On the contrary, the result showed that eight students were worried about the utterances that they produced, whether it was understandable or not. It was due to the unclear pronunciation and some issues dealing with grammar and vocabularies. This situation was a reflection to what had been explained by (Ahmed et al., 2017) stating that anxiety was bound not only to the willingness to speak up but also to the quality of the communication. Thus, the anxiety led the students to worry about the quality of their utterance that they said.

The third factor influencing the students' anxiety was due to the learning environment. Five students were anxious during the video recording process. The process did not require them to face public audiences, but they were still anxious about it. About that occurrence, the students were so worried about the result of the video that could be accessed by the public. Six students expressed their anxiety due to YouTube publicity result. It was in line to what had been said by (Ahmed et al., 2017) saying that the students were anxious when they were asked to speak in front of their friends. Although YouTube enabled the speaking activities not to face public audiences, the students still suffered anxiety through the video recording process. The result that was published in public made them anxious since all of their classmates and also people in general who accessed YouTube, could see their English performance. Then, 11 students perceived that their anxiety came from the unfamiliarity in using the English language. They said that they were not accustomed to speaking in English. When the students found the topic of communication to be unfamiliar, they were unwilling to speak up (Kasbi \& Elahi Shirvan, 2017). This occurrence happened due to the limited exposure and limited opportunities outside the classroom to practice their English speaking (Zhang, 2009).

\section{No anxiety in the YouTube video project}

59 students out of 124 students did not perceive any anxiety during the YouTube video project. Two significant factors made them feel confident in doing the project. The first one was personal perception. Twenty-seven students believed that the activity of making a video on 
YouTube allowed them to improve their English. It was confirmed by (Nikitina, 2010) that video project on YouTube provided learning activities in a more meaningful setting.

Moreover, 11 students did not worry that making mistakes was a part of learning. They believed that making mistakes was normal, so there was no need to feel guilty or fearful of making mistakes. This belief was on the contrary with (Mahmoodzadeh, 2012) stating that making grammatical errors was one of the significant causes of anxiety. Then, three students felt positive about the vocabularies that they used, so it supported them to speak up in English. Thus, students' positive self-perception helped them in speaking and lessened their anxiety.

The second factor that gave impact to the absence of anxiety was the learning environment. Fifteen students felt positive due to the process of video project making since the only people who watched their English performance was only their group mates. It was similar to the idea proposed by (Ahmed et al., 2017) stating that students felt anxious when they had to speak up in front of many people. Since video making was not done in front of many people, the anxiety did not exist in the process of learning. Moreover, seven people felt that the process of video project making was flexible due to the preparation time that was longer and flexible. Then, eight students were comfortable with the fact that the result of the video project can be edited and revised. When the students perceived that the result of their English performance did not meet their expectation, they could quickly retake the video or edit and change it. It portrayed the shifted of learning environment from the traditional one into today's electronic learning culture (Duffy, 2008). The learning environment was matched to the characteristics' of today's students. Next, two students felt that YouTube video project gave them more freedom in practicing the language, and eight students perceived that it became a fun method to learn English. Those responses confirmed the ideas that YouTube video project brought highly motivating impact to the learners since it created excitement, challenge, and meaningful context of learning (Hafner \& Miller, 2011) and (Vanderplank, 2010). Thus, it made the students felt better when learning English. Lastly, three students considered that they thought no anxious since they were accustomed to speak in English. The more the students got a chance to talk in English, the less they felt anxious due to the exposure of English that they got. It was in line with (Kasbi \& Elahi Shirvan, 2017) saying that when students got many opportunities to speak, they were more willing to talk due to the familiarity of the topic. Thus, the learning environment 
of YouTube video project was perceived to be positive by 59 students that hinder them from the anxiety.

\section{Students' preferable activity for speaking practice}

According to the research result, 104 students preferred YouTube video project. They felt that YouTube made them less anxious compared to other speaking activities. (Roodt \& Peier, 2013) stated that YouTube video project provided an innovative platform that engaged today's students in language learning. He also added that YouTube video project provided flexible learning and in-depth exploration for the students in the level of undergraduate and postgraduate. Also, (Duffy, 2008) confirmed that YouTube video project was a valuable learning exercise. Then, there were a few numbers of students that were 20 students preferred learning activities other than YouTube video project. However, this number was so little compared to those who preferred YouTube video project. Based on this result, the researcher noticed that YouTube video project provided the learners less anxious learning environment compared to other speaking activities.

\section{Discussion}

The finding of this study revealed that the students' anxiety existed in the YouTube video project. However, the comparison of the result between the students who felt anxious and did not felt anxious is 65:59. Those number was slightly different. The result that showed the number of the students who felt more anxious was on the contrary with the studies conducted by (Hafner \& Miller, 2011) and (Vanderplank, 2010) who discovered that video project is believed to be an effective media to lessen the anxiety since it appears providing a highly motivated impact to the students that they can find exciting, challenging and meaningful learning in it. Furthermore, the result of this study was also different with the study of (Nikitina, 2010) that revealed video project learning eases the learning process because it gives learners' chance to practice the language in a more meaningful context with their strategies.

However, from the result of the video project that was compared to other speaking activities, YouTube video project became the most preferred media that was based on the 104 students and the rest 20 students preferred other speaking activities such as storytelling, oral 
presentation, and delivering a speech. Big number of the students choose YouTube video project as the media for the speaking activities that they like the most. Previous studies are in line with that result. The study that was done by (Ellis, 2012) also shows video project learning provides a less threatening learning environment compared to the individual learning activities that put them in a more under pressured situation. Then, (Tercan \& Dikilitas, 2015) stated that speaking skills teaching should be done in socially non-threatening setting. Accordingly, YouTube video project can be one of the alternative to achieve that kind of learning environment.

The conclusion from the research question 1 showed that students still felt the anxiety during the YouTube video project. However, YouTube video project has been successful in creating less-threatening speaking environment compared to other speaking activities. Then, the major factor that gave impact to the existence of anxiety was being afraid and embarrassed of making mistakes. Meanwhile, the major factor that support the absence of anxiety in YouTube video project was due to the students' belief that video project was a media to improve their English skills.

\section{CONCLUSION AND SUGGESTION}

\section{Conclusion}

The research has objectives to examine the presence and the absence of anxiety in the YouTube video project along with the factors influencing it. The research finding showed that more students feel anxious about doing the YouTube video project. The factors causing this occurrence are due to students' low personal perception, peers' negative judgment, and quite intimidating learning environment. However, there is a slightly different number of students who do not feel anxious. The factors that support this occurrence are students' positive personal perception and fun-less intimidating and encouraging learning environment. Moreover, it is also proven that despite the students' anxiety, YouTube video project gets the highest preferences among other learning activities in speaking. YouTube video project is successful in establishing a less anxious learning atmosphere compared to storytelling, speech, and oral presentation activities.

Premise Journal Vol. 8 No 2, October 2019, e-ISSN: 2442-482x, p-ISSN: 2089-3345, p.176-192

Copyright@2019 by PJEE 


\section{Suggestion}

For future research, it is suggested to investigate more learning applications by using the YouTube video project that may establish a less anxious learning environment for speaking practices. Moreover, exploration of the current theme that is correlated with the students' future needs should be done by the teachers to provide meaningful learning for the students.

\section{ACKNOWLEDGMENT}

We want to express our thanks to Universitas Bina Sarana Informatika for supporting us to conduct our research investigating the issue in English education. We also really appreciate the 124 students of the non-English department at Sanata Dharma University, Yogyakarta for their insightful information as the data of this research. Also, for our families, colleagues, and friends, thank you for your invaluable support.

\section{BIO-PROFILE}

Angela Bayu Pertama Sari and Dwi Iswahyuni are English lecturers in Universitas Bina Sarana Informatika. They are passionate to investigate issues related to English teaching for nonEnglish students. This study is one of the research interests that they both work together on. Corresponding email: angela.abp@bsi.ac.id, dwi.dhs@ bsi.ac.id

\section{REFERENCES}

Ahmed, N., Pathan, Z. H., \& Khan, F. S. (2017). Exploring the Causes of English Language Speaking Anxiety among Postgraduate Students of University of Balochistan, Pakistan. International Journal of English Linguistics, 7(2), 99. https://doi.org/10.5539/ijel.v7n2p99

Aksel, A., \& Gürman-kahraman, F. (2014). Video Project Assignments and Their Effectiveness on Foreign Language Learning. Procedia - Social and Behavioral Sciences, 141, 319-324. https://doi.org/10.1016/j.sbspro.2014.05.055

Ansari, M. S. (2015). Speaking Anxiety in ESL / EFL Classrooms : A Holistic Approach and 
Practical Study. 2(4), 38-46.

Boonkit, K. (2010). Enhancing the development of speaking skills for non-native speakers of English. 2(2), 1305-1309. https://doi.org/10.1016/j.sbspro.2010.03.191

Bozavli, E., \& Gulmez, R. (2012). Turkish Students' Perspectives on Speaking Anxiety in Native and Non-Native English Speaker Classes. Online Submission, 12, 1034-1043.

Çağatay, S. (2015). Examining EFL students 'foreign language speaking anxiety: The case at a Turkish state university. 199, 648-656. https://doi.org/10.1016/j.sbspro.2015.07.594

Duffy, P. (2008). Engaging the YouTube Google-Eyed Generation: Strategies for Using Web 2.0 in Teaching and Learning. Electronic Journal of E-Learning, 6(2), 119-130.

Ellis, R. (2012). Language teaching research and language pedagogy. Oxford: John Wiley \& Sons, Inc.

Hafner, C. A., \& Miller, L. (2011). <Hafner\&Miller2011_VideoTechforScience_LLT.pdf>. 15(3), 68-86.

Hanifa, R. (2018). Factors generating anxiety when learning EFL speaking skills. Studies in English Language and Education, 5(2), 230-239.

https://doi.org/10.24815/siele.v5i2.10932

Harmer, J. (2004). The Practice of English Language Teaching (6th ed.). Harlow: Pearson Education Limited.

Kasbi, S., \& Elahi Shirvan, M. (2017). Ecological understanding of foreign language speaking anxiety: emerging patterns and dynamic systems. Asian-Pacific Journal of Second and Foreign Language Education, 2(1). https://doi.org/10.1186/s40862-017-0026-y

Kawulich, B. (2015). Qualitative Data Analysis Techniques. (January 2004).

Mahmoodzadeh, M. (2012). Investigating Foreign Language Speaking Anxiety within the EFL Learner's Interlanguage System: The Case of Iranian Learners. Journal of Language Teaching and Research, 3(3), 466-476. https://doi.org/10.4304/j1tr.3.3.466476

Premise Journal Vol. 8 No 2, October 2019, e-ISSN: 2442-482x, p-ISSN: 2089-3345, p.176-192

Copyright@2019byPJEE 
Miles, M. B., Huberman, A. M., \& Saldana, J. (2014). Qualitative Data Analysis. Washington DC: SAGE Publications, Inc.

Nikitina, L. (2010). Video-making in the foreign language classroom: Applying principles of constructivist pedagogy. Electronic Journal of Foreign Language Teaching, 7(1), 21-31.

Nurlaili, I., \& Kurniasih, E. (2016). AN ANALYSIS OF STUDENTS’ SPEAKING ANXIETY IN PUBLIC SPEAKING CLASS IN ENGLISH DEPARTMENT OF UNIVERSITAS NEGERI SURABAYA AN ANALYSIS OF STUDENTS' SPEAKING ANXIETY IN PUBLIC SPEAKING CLASS IN ENGLISH DEPARTMENT OF UNIVERSITAS NEGERI SURABAYA. RETAIN Journal, 4(2), 43-51.

Roodt, S., \& Peier, D. (2013). Using Youtube (C) in the Classroom for the Net Generation of Students. 10.

Tan, E., \& Pearce, N. (2011). Open education videos in the classroom: exploring the opportunities and barriers to the use of YouTube in teaching introductory sociology. Research in Learning Technology, 19(sup1), 7783. https://doi.org/10.3402/rlt.v19s1/7783

Tercan, G., \& Dikilitas, K. (2015). EFL students' speaking anxiety: a case from tertiary level students. ELT Research Journal, 4(1), 16-17.

Vanderplank, R. (2010). Déj vu A decade of research on language laboratories, television and video in language learning. Language Teaching, 43(1), 1-37.

https://doi.org/10.1017/S0261444809990267

Zhang, Y. (2009). Reading to Speak: Integrating Oral Communication Skills. English Teaching Forum, 47(1), 32-34. Retrieved from http://eproxy.lib.hku.hk/login?url=http://search.ebscohost.com/login.aspx?direct=true\&d $\mathrm{b}=$ eric $\& \mathrm{AN}=\mathrm{EJ} 923446 \&$ site $=$ ehost-live $\&$ scope $=$ site 